\title{
Intricacies of Practical Wisdom: Or Wby Would Aristotle Vote for Pericles Ratber Than Lenin?
}

\begin{abstract}
The article discusses the concept of practical wisdom (phronesis), which for Aristotle plays the crucial role in political activity. Unlike philosophical wisdom (sophia), phronesis requires knowledge of particulars, which are things capable of 'being otherwise'. Such knowledge cannot be attained once and for all as universal truth, but must be constantly revised and updated to meet the requirements of future-oriented political actions. Thus it seems to be similar to Aristotle's understanding of an opinion, which is for him the outcome of dialectical reasoning, distinguished from scientific reasoning relying on demonstration. Dialectics can be viewed as a key to politics, and the fact should not be overshadowed by criticism towards those thinkers and politicians who, like Lenin, used it with no respect for the difference between truth and opinion. Comparing Lenin to Pericles, who is directly called phronimos (practically wise) in Nicomachean Ethics, leads to the conclusion that critical examination of different political standpoints should not be limited to ideas, concepts, or proposals they put forward, but should also consider the deeper level of political reasoning standing behind them. It is argued that the lack of proper usage of the dialectical faculty can inflict serious damages both in political theory and political practice.
\end{abstract}

Keywords: political theory, political philosophy, ethics, Aristotle, practical wisdom, dialectics.

Słowa kluczowe: teoria polityki, filozofia polityczna, etyka, Arystoteles, mądrość praktyczna, dialektyka.

If judged according to Quentin Skinner's famous article Meaning and Understanding, ${ }^{1}$ which is still a useful examination of conscience for a historian of political thought, the very title of this article could be accused of committing at least several methodological sins. Is it not an anachronism to bring together Aristotle and Lenin? It would be all the more unacceptable since there was nothing similar to Communism in antiquity, so not a word about it can be found in the works of the ancient philosopher. And Pericles? Aristotle mentions him several times, but usually without much sympathy. On what basis, then, does the author claim to understand Aristotle's political taste better than

1 Q. Skinner, Meaning and Understanding in the History of Ideas, "History and Theory" 1969, Vol. 8 (1), pp. 3-53. 
the philosopher himself? All that seems to be at least suspicious, or even suggestive of deficiencies in methodological awareness on my part. However, as I will try to show, appearances can be misleading. It is not my intention to declare ahistorical intellectual wars between concepts and ideas as distant as Aristotle's, Pericles', and Lenin's. In fact, to a large extent I will neglect what we tend to take for the core of 'political thought' as such, namely: different prescriptions for good political order as suggested by the particular thinker. Instead of focusing upon what they have to say, I intend to judge them on the basis of how they say it. I believe, that if my opinion turns out to be convincing (the word 'opinion' is used here on purpose, as it should be revealed later), it can be argued that the history of political thought is not only a rich repository of particular political concepts, but also gives insight into intricacies of political thinking as such. Unlike political thought, which is inevitably bound to ever changing historical circumstances, political thinking depends first of all on human cognitive capacities. This fact makes it much more universal. As Jerzy Szacki summarised, the greatest thinkers of all times have no history, and their works belong simply to our shared universum of deliberation and discourse. ${ }^{2}$ If so, then careful examination of different ways of political reasoning in the past can have not only theoretical but also practical value. At least until Giovanni Sartori's prophecy proves to be fulfilled and homo sapiens is replaced by homo videns.

Let me refer to a simple analogy to better clarify a general thesis of this article. If we want to buy a house, and try to determine whether it is worth the price the seller wants, we usually begin with exploring its interior. We inspect every room, assess its size, comfort, and so on. We ask and take into account all possible details that may come to our mind - from the quality of building materials, through the layout of rooms, to the sum of the maintenance costs. We tend to adopt the same attitude towards philosophical literature. We take books for solid and accomplished works and, turning one page after another, we find the expressed views either attractive or discouraging. Either we feel at home, or like in some strange place we want to leave immediately.

In buying a house, there is little chance that we paid any attention to what had happened before. That is, to the process of building it. This kind of knowledge seems to be relevant only in as far as its outcomes are visible and have already enchained our attention. Still, many aspects of the process of building which are not to be noticed at first glance influence the future condition of the house and may cause problems when we move in. What if bricks are solid, but the mortar has not been mixed in proper proportions? Or some pretty wallpaper was stuck on the bathroom walls without checking its waterproofness? To learn all that, different questions must be asked and to ask them requires some expertise in the 'methodology' of building. The same is true about political theories. Behind the final shape of every theory stands some process of constructing it; an effort of thinking of a different character and quality. And so, just as a house is an outcome of the whole process of building, every political theory is an outcome of particular thinking. Criteria of assessing these two aspects of the same thing - either the house, or the theory - differ, and we are usually satisfied with scrutinizing the content of the given theory, just as we confine ourselves to looking over the house. Only if some

2 J. Szacki, Dylematy historiografii idei [in:] idem, Dylematy historiografii idei oraz inne szkice i studia, Warszawa 1991, p. 14.

Artykuły - Articles 
apparent elements of the theory directly disclose some methodological benefits or difficulties, do they gain more profound, though still rather partial, interest.

It is worth noticing that the knowledge of methodology may lead to conclusions contradictory to opinions based on observing what we get as the final outcome of both building a house and exposing a political stance. Seeing brand new and extraordinary wallpaper in the bathroom, we may feel tempted to buy the house. Finding out that this wallpaper can be destroyed by water suggests quite the opposite. What should we do? Unfortunately there is no algorithm we could apply to simplify the process of arriving at a final decision, which would also be resistant to doubt once we have made it. The future of the house, and the comfort of our living in it is partly uncertain, as all that will depend to a large extent on our choices, actions, and investments. Using the bathroom we will notice sooner or later that the wallpaper starts to deteriorate, but even then its fate cannot be foretold for sure. Perhaps we replace it right away. Still, if our determination to preserve the beauty of the wallpaper is great enough, we will be able to find ways to save it much longer than the objective fact of its lack of waterproofness would suggest. There are plenty of such ways, some of them very creative. Perhaps we will become more careful while taking a shower. Or maybe we could use a shower at work from time to time. No shower at work? Well, who says we cannot change jobs? Or why not ask a neighbour to rent out his bathroom once a week for an appropriate fee?

Funny as it may seem in the case of a bathroom, the analogy with political theories still works and is much less funny. Against the thesis of the forthcoming end of ideology put forward decades ago, there are still plenty of different political ideas ready to be bought and inhabited as convenient cognitive shelters, allowing one to understand the political world, to feel safe in it, and perhaps to contribute to designing some of its parts anew. They are created to be used in practice, just as a house is constructed to be lived in day by day. With time every theory, again like every house, requires smaller and greater investments, renovations, and actions like cleaning to keep it in good condition. It seems to be, however, an important difference between such natural refurbishment and the decision to save the wallpaper at the expense of daily hygiene. This latter decision is 'practical' in the sense that it shall influence and modify the everyday practice, presumably in a profound way. Still, calling such practice 'practical' sounds suspicious in comparison to less spectacular practices which would permit the use of the bathroom as a bathroom. Is there a way to express this suspicion in terms which would be able to point at sources of such 'impracticality'? Universal enough to convince not only those who see the absurdity of the situation, but also those who like the wallpaper so much that they might consider bringing that absurdity to life?

We have learnt by historical experience that some political ideas, attractive as they were while being born, turned out to be pernicious in the long term. Still, they managed to attract many - including philosophers. They were put into practice, and, like Communism, they were maintained with no respect for the costs of such maintenance (economic, social, psychological, etc.). Of course the idea of a person who gives up washing only in order to let the wallpaper survive is unthinkable. Unthinkable from our contemporary perspective is also the fact that Communism could have attracted anybody. Even more unthinkable is that it could have attracted such notable minds as 
Leszek Kołakowski, who many years later admitted it to be the idea of 'fried snowballs'. ${ }^{3}$ Nevertheless, every criticism going in this direction has only limited significance, as its value is historical, ethical, and perhaps esthetical, but not political. Eventually we may buy a new house, and the history of the wallpaper may make us more careful as far as wallpapers are concerned, but it does not automatically provide us with tools to detect causes for all other hidden defects which will start to be bothering only with time. To become political, such tools should have some universal validity to allow us to examine every house a priori, and apart from its visible features.

Relying on the above analogy, this article aims at discussing several compatible issues. On the most general level it tries to identify some ways or modes of political thinking which are preferable to others as they allow the gathering of knowledge (thought) deserving of the name 'practical' political philosophy. To do so, it focuses on a possible answer to a reversed question: can some ways of political thinking cause structural defects so profound that by identifying them one would be able to formulate arguments which would discredit the particular theory no matter what its actual content? To translate the above into the language of the title of this article: can Aristotle appreciate Pericles' political thinking without supporting his political position? Would the philosopher be able to question Lenin's political wisdom, knowing nothing about Bolshevism or Communism, or even sympathizing with several of their general claims? I think that the answer to both these questions is yes, and arguments favouring this answer are at the same time arguments for the possibility of combining historical and political research without the risk of anachronism.

\section{Pericles and "men like him"}

Aristotle mentions Pericles only occasionally, but two such references are of particular interest here. In the Constitution of Athens the philosopher acknowledges Pericles' contribution to reinforcing Athenian democracy and admits that as long as he was at the head of the people 'the government went on better, but on his death it became much worse'. ${ }^{4}$ Does it mean that Aristotle advocates Pericles' political actions? Not at all. Discussing the famous decision of introducing payments for judges, he sees it as an encouragement of bribery in the law courts and thus the main source of future corruption of the state. And so on Aristotle's list of the best politicians of that time we find Nikias, Thucydides, and Theramenes, but not Pericles. ${ }^{5}$ In fact, even the sentence quoted above, which seemed to favour Periclesian politics in comparison with what was happening after his death, is rather an accusation against him; especially if we take into account the words of Aristotle's master. It is in Plato's Gorgias, where the example of Pericles (and exactly the same decision to grant payment to jurors serves Socrates to argue that politi-

3 See: J. Marks, Fried Snowballs, London 1990, p. 7.

4 Aristotle, Constitution of Athens, A.28.

5 Ibidem, A.27.

Artykuły - Articles 
cians who worsen the morals of their citizens are the worst politicians. ${ }^{6}$ And Pericles must have achieved exactly this, since things became much worse when he died. In this light Aristotelian opinion on Pericles seems to be even more severe.

And yet, in Nicomachean Ethics we read: "It is for this reason that we think Pericles and men like him have practical wisdom, viz. because they can see what is good for themselves and what is good for men in general; we consider that those can do this who are good at managing households or states". ${ }^{7}$ Short as it is, this remark on Pericles is more than a mere sideways politeness toward a well-remembered Athenian politician. 'Practical wisdom' (phronesis) is for Aristotle one of the key concepts which allow the distinguishing of his stance in ethics and politics from that of Plato's. So there are reasons to assume that he was rather careful with choosing his example. If Pericles is phronimos - practically wise - then he is to be appreciated as a good politician.

How does one reconcile two perspectives, two judgements, which are clearly contradictory? Is it possible to criticize Pericles and yet value him at the same time? Referring to Aristotle I want to argue that it is not only possible, but also plausible. To understand this point it is necessary to look briefly at Aristotle's concept of phronesis.

Phronesis occupies a special position within Aristotle's notion of the human soul. ${ }^{8}$ Being a 'wisdom' it is a virtue of intellect, thanks to which we can grasp a rule, or rational principle. ${ }^{9}$ Still, unlike the other virtue of the same kind - sophia - it cannot provide us with knowledge on "things whose originative causes are invariable"10 (scientific knowledge, episteme), but only on "things capable of being otherwise". ${ }^{11}$ What could be seen as a deficiency in respect to knowledge and acquiring the truth is, however, an important benefit when we take into account the 'practicality' of phronesis. Exactly because it refers to variable things, it governs actions and prevails in the sphere of 'things to be done' (praxis), that is, 'human affairs', such as creating and maintaining the city-state. ${ }^{12}$ And so phronesis also has a lot in common with moral virtues, since "moral virtue is a state of character concerned with choice", ${ }^{13}$ and choice is the origin of action. Adding to this that a choice is "desire and reasoning with a view to an end" ${ }_{14}^{14}$ it becomes obvious that Aristotle sharply distances himself from Plato's political theory. According to the latter, a sage, and even better, a group of sages, would make the best rulers of any city-state. This is exactly because their intellects are filled with wisdom which is the knowledge of universals, and these are things which cannot be otherwise, as they are perfect and eternal. To avoid any contamination of sophia Plato goes as far as to block every possible influence of the desiring part of the soul on a sage's actions, thus leaving no place for

Plato, Gorgias, 502e-503d.

Aristotle, Nicomachean Ethics, 1140 b.

8 For a detailed analysis see an excellent and short entry: J.-L. Labarrière, Phronesis [in:] Dictionary of Untranslatables: A Philosophical Lexicon, E. Apter, J. Lezra, M. Wood (eds.), Princeton-Oxford 2014, pp. 777-783.

\footnotetext{
9 Ibidem, p. 780.

10 Aristotle, Nicomachean Ethics, 1139a.

11 Ibidem, 1139b.

12 J.-L. Labarrière, Phronesis..., p. 780.

13 Aristotle, Nicomachean Ethics, 1139a.

14 Ibidem.
} 
phronesis as the basis for ethics, unless it is 'fastened' to universal truth. ${ }^{15}$ A Platonian sage - either a ruler in a perfect republic, or a mere citizen - knows for certain, and so his eventual deliberations or conjectures are meant mainly to recollect wisdom and not to acquire new (all the less different) understanding useful for acting. The actions of a sage are rooted in the objective and necessary truth, and this truth vouches for their being good by definition. There is only one truth, and so such action does not include any choice. For Plato it is unthinkable that a wise person could choose to do anything but the good, ${ }^{16}$ which is at the same time individual and common good, whether recognised as such by others or not. And vice versa, a person with phronesis only has never acquired the truth, so his knowledge lacks the certainty which is necessary for any action to be unequivocally good. Plato compared such a person to a guide who knows a way to Larisa, and wants to get there, but because he has never actually been to the city, others cannot be sure if he eventually is leading them in the right direction. ${ }^{17}$ The problem with the guide seems to be that he is condemned to choose at every turn, while a sage is always certain about the way ahead.

Aristotle emancipates politics from philosophy. Humble as he is in admitting that phronesis is in a way inferior to sophia,$^{18}$ Aristotle would not agree with the message coming from the above comparison from Meno. Indeed, a guide who has been to Larisa will be able to get there again more quickly, but having acquaintance with the location of the city does not necessarily make anybody a good guide. Being a guide includes being able to sustain relationships with those who are guided; those, who do not know the way, and quite often are not even sure if they want to go any further. It is not enough for the guide to keep his mind focused on the ultimate end of the trip, as if the guide's goal is to be rewarded for the guidance. His main energy should be applied towards encouraging others to follow him. To do that he has to focus on the particular situation he and the others are currently in. The truest scientific knowledge on Larisa (episteme) can help neither in understanding that, nor in inferring right means to continue the concerted journey.

The problem for Aristotle is not that sophia has no practical value. Quite the contrary, purely scientific knowledge may be very beneficial. In Politics Aristotle tells the anecdote on Thales the Milesian, who - being tired of people laughing at the uselessness of his philosophy - used his astronomic observations to become rich. Predicting in winter a great harvest of olives in the coming year, he was the first to give deposits for the use of all the olive-presses in Chios and Miletus, and so during the harvest everybody had to pay him for letting the presses out. ${ }^{19}$ This way he proved that universal knowledge of the stars can be put into practice and bring practical outcomes which in turn have political significance. With skills like this if Thales had only wanted, he would have been able to improve his status within his political community. Of course that is not the goal of a philosopher (and Thales did not care about his spectacular richness), but there are many others who do similar things, relying on the sophia of philosophers. Aristotle gives here another example of 'a man of Sicily', who, like Thales,

15 Plato, Meno, 97e-98a.

6 See: B. Jowett, Selected Dialogues of Plato, New York 2001, p. 85.

17 Plato, Meno, $97 \mathrm{a}-\mathrm{c}$.

18 Aristotle, Nicomachean Ethics, 1141a.

19 Idem, Politics, 1259a. 
had the good fortune to create a monopoly. Here, however, the conclusion of the story is slightly different. ${ }^{20}$ The man was allowed to keep his money, but he was forced to leave Syracuse. His self-interest was preserved, but, accepting the Aristotelian view on human nature, one is forced to interpret his actions as objectively bad, proving a lack of any phronesis, and thus lacking the strictly human capacity to achieve individual goals through mutual cooperation with others.

It is worth emphasizing that the fact that sophia is a kind of wisdom which can be put into practice does not make it practical wisdom (phronesis). Not only does Aristotle emancipate politics from philosophy this way, but he also suggests that it is closer to ethics, as ethics regulates the domain of interpersonal relationships, which are in general a dynamic struggle to negotiate between extremes to achieve the famous 'golden mean'. Phronesis cannot then be separated from ethics, because, just like other ethical virtues, it requires education, experience, and time. ${ }^{21}$ On the whole, political activity is by nature an ethical enterprise, as only the pursuit of human good justifies actions which cannot be justified by reference to invariable principles. Only then can such actions be future-oriented and executed without a fear that the choice made is not the best amongst all possible choices. Since phronesis works upon uncertainties and things which can be otherwise, it can never demonstrate its absolute correctness. To say it bluntly, here the action itself vouches for the wisdom standing behind it, and not the other way around.

Even though it may look like the few previous paragraphs describe what phronesis is, they actually do not, and the fact is not irrelevant. So far the main focus was concentrated on two elements: the 'practicality' of practical wisdom, and its being different from sophia (thus explaining what phronesis is NOT). Important as they are, neither of these two elements grasp the 'wisdom' part of practical wisdom. And as long as we do not have any clues in this respect, it is impossible to tell whether Pericles deserves to be called phronimos or not.

\section{Dialectics as a key to politics}

Practical wisdom is not superior to philosophical wisdom (sophia) "any more than the art of medicine is over health; for it does not use it but provides for its coming into being; it issues orders, then, for its sake, but not to it". ${ }^{22}$ A physician does not have the power to decide what health is, but, knowing what health is, he can cure his patients' illnesses. To do the latter, however, requires more than true knowledge of health. A good physician knows for instance, that children usually hate taking pills, and so he is able to figure out different ways (means ${ }^{23}$ ) to bring them to health. It is his phronesis which allows him to

20 In Nicomachean Ethics (1141b) Aristotle is more straightforward in claiming that Thales and other philosophers, though wise, lack phronesis.

21 Idem, Nicomachean Ethics, 1103 b.

22 Ibidem, 1145a.

23 Here I leave aside an interesting (although not so much for Aristotle) problem of the relation between means and ends. Aristotle assumes that good goals can be achieved only by good means. It can be conceived that a physician simply pushes a pill through a child's throat to cure him. Such an action can be called 'clev- 
adjust proper means to assumed ends in this particular situation. And such wisdom, according to Aristotle, is the effect of a particular kind of reasoning, carried out by the part of the soul which forms opinions.

Here we get down to a deeper level of the soul's activity; the very process of acquiring particular wisdom. If there are (Aristotle seems to be certain about it) different types of reasoning standing behind the wisdom we gather, then the differences between them must be in some way reflected in the final outcome of reasoning - the wisdom itself. They influence such qualities as for instance its status, value, or resistance to doubt. To use again the analogy introduced at the beginning: looking around a house we see particular walls. They seem to be just walls, of different size and colour perhaps, but simply walls to be treated like walls. We might like to hang a painting on one, and make a doorway in another. However, to do this in a proper way we should differentiate first between load-bearing walls and others. To do that we must refer to the architect's sketch and to the principles of the whole construction of the house, as they limit, or at least partly determine our actions towards the walls. It is possible of course to remove a load-bearing wall if we like, but the risk is greater, and compensative actions to protect the whole building more expensive. The same, I think, is true about political theories, if we are to consider their practical use. They consist of many statements which differ not only in respect to their content (that is, to 'what they say'). Equally important is their history - the whole process during which they were created and became "states of the soul" 24 - as this process preordains conditions of their future use. Obvious as they seem in the case of a house, such differences are not easily noticed and examined in the case of political theories. Aristotle seems to be one of not so many philosophers to discern and to welcome diversity of our cognitive tools, but at the same time to specify their limits.

"For opinion is about the variable - summarizes Aristotle - and so is practical wisdom". ${ }^{25}$ Whereas at the beginning of Topics we read:

[...] reasoning is an argument in which, certain things being laid down, something other than these necessarily comes about through them. (a) It is a 'demonstration', when the premises from which the reasoning starts are true and primary [...] (b) reasoning, on the other hand, is 'dialectical', if it reasons from opinions that are generally accepted. ${ }^{26}$

The word opinion ( $d o x a$ or rather endox $a^{27}$ ) usually appears in Aristotle's works against the background of dialectical reasoning, contrasted with scientific demonstration. And it is the difference between science and dialectics - respectively: scientific wisdom and an opinion - which makes the split between sophia and phronesis both more profound and more serious as far as politics is concerned.

Bertell Ollman claims (quite dialectically) that it is easier to explain what dialectics is not rather than what it is ${ }^{28}$ Richard McKeon doubts "the possibility of defining dia-

er', but cleverness which forgets about the starting-point of the action (which in this case is general 'health', and not simply 'making a child swallow a pill') is not practical wisdom (Nicomachean Ethics, 1144b). This is the assumption questioned later by Niccolò Machiavelli in his Il Principe.

24 Aristotle, Nicomachean Ethics, 1138b.

25 Ibidem, 1140b.

26 Aristotle, Topics, 100a-b.

27 B. Cassin, Ch. Baladier, Doxa [in:] Dictionary of untranslatables..., p. 230.

28 B. Ollman, Dance of Dialectic: Steps in Marx's Method, Urbana-Chicago 2003, p. 12. 
lectic unambiguously or of distinguishing clearly between dialectical and non-dialectical methods". ${ }^{29}$ Both these statements are true, but their implicit suggestion that dealing with dialectics involves a great dose of intellectual confusion is not neutral. Such disregard is due to the adventures of G.W.F. Hegel's dialectics, transferred to Marxism and then Communism; doctrines which were responsible for causing serious abuses to political practice in many European countries and other parts of the world. Nevertheless, no matter how ethically justified, views like Ollman's and McKeon's miss the point. They seem to take for granted an assumption instilled in European culture by a positivist paradigm the paradigm which has been arguing that the only non-violent cornerstone for politics is science. In my opinion the premises of positivism, often jointly with modernism, are no longer sustainable, and one does not have to be a postmodernist to join its critics and express some "incredulity toward metanarratives". ${ }^{30}$ Many voices demand serious rethinking of what we are to call political practice, to not reduce it to technical aspects of exercising power on one hand, and inescapable cultural wars and values clashes on the other. It is no accident that many authors who try to remind us about a much wider notion of the political, refer to Aristotle and his insistence on ethics as the basis for political practice. Unfortunately, rarely do they take dialectics under careful consideration, which, I believe, is a serious negligence. Dialectics deserves rehabilitation, especially if we are to follow Aristotle, who regarded it as being essential to ethical (and thus also political, since the two are mutually related) discourse.

In general, the meaning of the term dialectics was for the Greeks the art of wise conversation ${ }^{31}$ or more precisely, a method of producing knowledge, preferably in dialogical manner. ${ }^{32}$ Given the etymology of the word, dialectical reasoning paves the way through different opinions and gathers, or picks up, different particles which are then used to complete new understanding. ${ }^{33}$ Still, the question remains, as to what we find at the end of this road. What kind of knowledge do we get as an outcome?

The answer to this question once again allows the contrasting of Aristotle with Plato. The latter claims dialectics to be the only way to the truth, and so he counts it as a crucial tool appointed by philosophers. ${ }^{34}$ Discussing opinions, or rather discrediting them one by one, a philosopher frees his mind from particular doxai. Opinions vary - Plato admits - but for him this is exactly the reason for giving them up, or rather for using them as steps for the soul, which, thanks to dialectics, is 'lifted upwards', ${ }^{35}$ to participate continuously in the universal truth, existing in the world of ideas. Plato explains

29 R. McKeon, Dialectic and Political Thought and Action, "Ethics. An International Journal of Social, Political, and Legal Philosophy" 1954, Vol. LXV (1), p. 16.

30 J.-F. Lyotard, The Postmodern Condition: A Report on Knowledge, transl. G. Bennington, B. Massumi, Minneapolis 1993, www.faculty.georgetown.edu/irvinem/theory/Lyotard-PostModernCondition1-5. html (access: 3.04.2018).

31 See a footnote in: Plato, The Republic (in Polish), transl. W. Witwicki, Kęty 2003, p. 218.

32 W. Stróżewski, Istnienie i sens, Kraków 1984, p. 123.

33 The productive character of dialectics and its ability to gather elements of new knowledge (legein in Greek means also 'to gather') are features emphasized by Martin Heidegger: idem, Hegel und die Griechen, Lecture in Heidelberg, 26.07.1958; English translation online: Hegel and the Greeks, www.morec.com/hegelgre.htm (access: 03.04.2018).

34 Plato, The Sophist, 253d-e; The Republic, 511c-e.

35 Plato, The Republic, 511b. 
his standpoint: "As being is to becoming, so is pure intellect to opinion. And as intellect is to opinion, so is science to belief, and understanding to the perception of shadows." ${ }^{" 36}$ This is another way to say that philosophers are superior to politicians, just as the eternal truth is superior to ever changing political practice. If people only trusted sages (assuming they were so fortunate as to meet Platonian sages) then the whole political practice would turn into a simple craft (techne), and so we could create an eternal and unchangeable, simply the ideal, polis.

Aristotle's works allow for the finding of a few flaws in the above argument. First of all, the knowledge universal enough to fulfil Plato's expectations of being static and invariable is the knowledge on forms, which means understanding the ultimate ends of particular substances (like human beings) and laws stimulating their development towards these ends. It is silent in regard to particulars that the politician deals with. Second, dialectics may be "a process of criticism wherein lies the path to the principles of all inquiries", but such inquiries are not to be carried on dialectically. ${ }^{37}$ Third, for Aristotle our interest in 'being qua being' contributes less to the development of our human nature than studying 'the becoming', that is: things in motion (the subject of Physics). ${ }^{38}$ Last, but not least, dialectics does not lift the soul up (heading at pure generalities), but rather leads it forward, to meet the future. The basic function of phronesis is exactly staying close to the world of particulars, ${ }^{39}$ upon which we act as doers, creating things which are in power to influence, but not to determine, our future. ${ }^{40}$ That is what makes dialectical opinions close to practical knowledge.

Thanks to the strategy of coherence ${ }^{41}$ dialectic reasoning can transcend the world of accomplished facts without being accused of dreaming only. In other words, it allows for the drawing of conclusions from actual particulars and the formulating of opinions concerning the future in order to make these opinions a cognitive element of wisdom necessary for flexible political practice. The only condition for success in this respect is that the reasoning stay close to particulars and reject the Platonian temptation towards generalisation and abstraction. As we shall see, this temptation is indeed strong, and can lead a politician astray.

Having an opinion well justified thanks to dialectical method strengthens the subjective certainty about the goodness of the action to be taken, even though this kind of certainty does not guarantee the action would be objectively effective, as the action itself is performed under conditions of uncertainty. Not only must the deliberative part of phronesis include the presumption that things can be otherwise in general, but also the action must include awareness that things may actually turn out otherwise. Accepting both these assumptions the phronimos must at the same time accept individual responsibility both for being wrong in his opinions and for doing wrong in his actions. And since doing is secondary to deliberation, in a situation like that, it is not enough to alter

36 Ibidem.

37 Aristotle, Topics, $101 \mathrm{~b}$.

38 See for instance: Posterior Analytics, 71b; Prior Analytics, 68b; Physics, 184a; Metaphysics, 1029b; Topics, 141b-142a.

39 Aristotle, Nicomachean Ethics, 1142a.

40 Ibidem, 1139b.

41 Ibidem. 
actions to get back on the right path. One should first of all use his phronesis to correct opinions and their underlying reasoning. That is another important difference between those who, like Aristotle, take an opinion for a wisdom more valuable in politics than the truth, and those who claim the truth to be sufficient for practice of any kind, including political practice. If a particular action turns out to be wrong, then Aristotle would suggest not only choosing a different action, but also examining the opinion prompting one to take such an action, and perhaps the reasoning leading to the opinion. Such a deep re-examination is impossible if the action is rooted in the truth.

All that proves that right from the start Aristotle appoints dialectics in politics, as an important part of phronesis. Dialectical reasoning struggles with opinions and the successful effect of such struggle is also an opinion..$^{42}$ and not truth as such. Opinion is at the same time less and more than truth. Less, because it can be questioned, as it is unable to demonstrate its premises. I would even say, the Aristotelian opinion deserves questioning, as this way the person holding it can prove his or her dialectical competence, and - strengthening the trustworthiness of the opinion - encourage others to share it. Comparing dialectic and rhetoric Aristotle makes it clear that both are simply 'faculties for providing arguments' ${ }^{43}$ Still, dialectical opinion is within the field of action (and hence, in politics) much more than the truth, because it provides the individual with knowledge necessary to engage oneself in action under the conditions of uncertainty. As uncertainty must be the state of affairs within the field of things which 'can be otherwise'. There can only be one truth. If we agree, just as Aristotle did, that the political community should embrace differences, as only differences motivate its development towards the common good, then the political discourse (ideas, concepts, theories) must include dialectics, which is important in gathering practical wisdom. Consequently, there is no sharp distinction between such political discourse and political practice, as dialectical opinions must be put into action to increase their reliability and to be convincing. Only truths are demonstrated by facts (things); opinions are completed by actions inferred directly from them, which in turn leads to the statement that politics is not 'making' good polis, but 'doing' things which are believed to be right. ${ }^{44}$ The final judgement on the last issue does not belong to the acting individual - it is a matter of a public recognition (a dialogue), which in turn makes politics a deeply ethical enterprise. And so Aristotle concludes that by being skilful in dialectics, one can better manage his relationships. ${ }^{45}$

Pericles was a democrat. As a democrat he held particular opinions and they influenced his final work - a project of a democratic polis, to the realisation of which he devoted his political activity. The most important thing in judging his practical wisdom is assessing consistency between his opinions, the actions which these opinions supported, and the effects of these actions. Opinions are not truths, so their content cannot be unequivocally demonstrated - what they claim can be brought to life only via individual action. And, inversely, by observing one's actions, it should be possible to

42 To trace practical application of this method it is enough to read Nicomachean Ethics or Politics. In both Aristotle starts with quoting and discussing opinions of other thinkers and only then introduces his own statements.

43 Aristotle, Rhetoric, I.2.

44 Aristotle, Nicomachean Ethics, 1140a-b.

45 Aristotle, Topics, I.2. 
reconstruct the opinions standing behind them. As a democrat Pericles was obliged to choose democratic means to strengthen democracy and thus to 'materialise' his political opinions. Viewed from this perspective, his decision to introduce payments for judges was a reasonable choice, proving his competence in practical wisdom. Even Aristotle's observation that this decision opened the door to corruption (which is to be treated as a demonstrative, historical statement) does not have to change this positive assessment of Pericles. What can be criticised, is not the phronesis of Pericles, but the opinion itself, namely, the argument that democracy is a proper form of government in which self-interests do not collide with aiming for the common good, and both are born out of freedom. ${ }^{46}$ Opinions may turn out to be erroneous, ${ }^{47}$ but if they do not hold pretence to being true, they are simply to be replaced by better opinions, and thus by better actions. Why not try a form of mixed government? Aristotle might put forward his own opinion.

Viewed as a whole, Aristotle's political philosophy seems to engage us all in political practice, either as politicians offering general political programs and particular solutions to particular problems, or as citizens supporting this or that concept and acting (or not) accordingly. The Periclesian project turned out to be attractive enough for the Athenians to trust it and to inhabit such a democracy. Having this practical support of the majority would not stop Aristotle from questioning Pericles's standpoint. Doing that, however, he would still be able to recognize and to appreciate his phronesis, which is similar to saying: 'I do not find the house you built to be the best house we could build to live in, but you have done a great work'. Unlike Plato, Aristotle accepts the naturally dynamic character of political reality. There are so many variables influencing its particular state that it would be impossible to predict it and so to gather knowledge sufficient to control it. That is why in politics it is far more practical to go beyond the truth and to invite reasonable deliberation on issues which cannot be grasped by sophia. Still, not every opinion deserves to become an active participant of such deliberative discourse.

\section{The 'impractical' practice of Lenin}

If we arranged an ahistorical political debate during which we asked Aristotle and Lenin to express their political views, we might be surprised to hear many quite similar statements from both. Similar at the surface at least, but it is the surface which usually draws the attention of those who are inclined to listen and who are to decide whose narration is more convincing.

Lenin would probably have agreed to many of Aristotle's points quoted in the previous subchapter of this article. Yes, there is no theory without practice, and practice means political action. Yes, political action is future-oriented and choosing means it takes into account particular conditions of action, while aiming at the ultimate happiness of mankind at the same time. Yes, actions having bad outcomes are to be called erroneous and

46 See: Pericles' Funeral Oration [in:] Thucydides, Peloponnesian War, Book 2.34-46, www.sourcebooks.fordham.edu/ancient/pericles-funeralspeech.asp (access: 3.04.2018).

47 Aristotle, Nicomachean Ethics, 1142a. 
the means they apply are to be abandoned. Yes, dialectical method leads us through the world of doubt and gives us, revolutionaries, a subjective certainty. Yes, Pericles was misled by his democratic desires. In fact 'simple' democracy is not the best option as long as citizens are not virtuous enough, so let us supplement it with a rule of an elite under the name 'democratic centralism'.

Would Aristotle feel any sympathy for Lenin? Would he be interested in joining Lenin or at least would he grant him his vote during the election? In my opinion the answer to all these questions is no. And such an answer has a much more universal value. If there are reasons to believe that Aristotle would be able to reject Lenin's position, no matter how he might have liked some of its elements, then perhaps it is possible to verify the 'practicality' of particular theories before they are put into practice; that is, before time and history shall demonstrate scientifically that their realization was on the whole pernicious and harmful.

Some biographers remark that Lenin lacked competence to carry out any kind of reasoning and that his theoretical works are at best 'lamentable' ${ }^{48}$ Nevertheless, it is one thing to have the capacity to attain some knowledge and skills without any help, and quite another to internalize a theory already being at hand. Lenin might have been unable to gather new understanding on his own, but fortunately for him that was unnecessary once he decided to become the pupil of Marx and Hegel. He wanted, after all, to become a politician and not a philosopher. So in spite of all scepticism, I join in the opinion of those scholars who claim that Lenin acknowledged the necessity of good theory to support political action. ${ }^{49}$

As I tried to argue at the start of this article in my reference to the analogy of the house, it is possible to suspend the analysis of the content of a particular political thought to examine the reliability of the whole process of thinking, out of which this content is born, and eventually to assess whether its declared practical potential is not overestimated (just like the value of the wallpaper in my analogy - looking good, but still not appropriate to be used in the bathroom). That is why I shall focus only on identifying features of Lenin's theory which suggest that there was something impractical in his views, if we trust Aristotle's notion of phronesis.

The crucial argument Aristotle could hold against Lenin would be his misuse of dialectics. Not the fact that Lenin had been constantly using dialectical method to support his political activity, because that is what a politician having practical wisdom does, but the fact that he did not grasp the difference between outcomes of dialectical versus scientific reasoning, namely the difference between opinion and the truth, and consequently his actions based on his knowledge do not deserve to be called 'practical' in Aristotelian terms (no matter how often Lenin himself would use terms 'practice', 'practical', 'pragmatic', 'realist', and the like).

Cultural anthropologists claim that one of the most striking features which characterize our European culture is a unique value attached to the concept of 'the truth'. Europeans seem to have a natural instinct for the truth, and the whole intellectual, politi$\mathrm{cal}$, and social development of our societies was stimulated by that visible drive to know

48 A. Ulam, The Bolsheviks, Cambridge 1998, p. 273.

49 A.V. Gouldner, The Two Marxism, New York 1980, p. 7-8. 
more and to know better, and in effect to change the world for the better. Until now both politicians and citizens have demanded the truth, expecting it to be a panacea to cure all evils. Marx and Lenin were driven by that instinct, as was Aristotle. The latter, however, seems to have been much more sensitive to peculiarities of thinking, and so his methodological awareness allowed him to notice that not every 'knowing better' is equal to 'knowing the truth'. There is wisdom, quite important, which should not be equated with the truth, because if it is, it impedes political practice of changing the world for the better. Lenin did not have any sensitivity for this. If others demand the truth from a politician to feel safe, then it cannot be denied that the truth has much greater political potential than any opinion. And if dialectical reasoning is useful in politics (which Aristotle could not deny) then the best politician should use it. So why not combine the two: dialectics and the truth? Lenin was not the first to get the idea. Plato and Hegel, both excellent thinkers, showed how to do it. Unfortunately, Lenin went a bit further and decided that the dialectical truth could not rule only theoretical speculations, but should be introduced to the world with no hesitation.

Aristotle's scrutiny allows for the probing of every political theory to diagnose its possible defects which would pervert political practice based on the knowledge they provide us with, no matter whether they are left or right wing. Lenin's standpoint is only an example here, but the best example perhaps, as all its theoretical sins which would be pointed out by Aristotle as prefiguring its impractical character, have materialised over the course of history. Here I shall discuss only a few, to justify the assertion that by using Aristotle's concept of phronesis, it is possible not only to identify concepts which improperly use dialectical opinions as objective truths, but also to predict at least a formal structure of actions of politicians promoting them. These are politicians, whom I would call 'unfettered dialecticians'.

Marx was obsessed with the truth, and throughout his life he tried to present himself as a scientist whose vocation was to expose falsehood. ${ }^{50}$ This self-identity must have been convincing to Lenin, since he decided to trust Marxism and to borrow from it the knowledge necessary to map out his revolutionary action. The truth Lenin extracted from the works of his famous predecessor - historical materialism supported by dialectical materialism (which was rather Friedrich Engels' improvement) ${ }^{51}$ - was, however, quite double-edged. On the one hand, as an outcome of dialectical reasoning, it had a lot of political potential in deliberation on 'things which can be otherwise' in the future, and so was very helpful in determining different ways to conduct a revolution. ${ }^{52}$ On the other hand, Lenin's insistence on treating such opinions as having a 'scientific truth' certificate, made actions inferred from them corrupted, even if effective. Just as the action of cutting off the water in the bathroom is effective in taking effective care of the wallpaper, but cannot be objectively viewed as being practical.

If dialectics is a way to the truth, as Plato would have wanted, then such truth must be as general and universal as possible. Two laws of socio-economic development formu-

50 I. Berlin, Karl Marx: His Life and Environment, Oxford 1996, p. 5.

51 See: G. Lukács, Geschichte und Klassenbewusstsein. Studien über marxistische Dialektik, Berlin 1923.

52 Lenin is often accused of not being coherent in his revolutionary proposals, but this accusation can be made only by someone who does not understand the creative power of dialectical method. 
lated by Marx and including the first principle (the birth of private property) and the final end (Communism) meet this criterion, and they became the kernel of Lenin's orthodox Marxism. Surprising as it may seem, Karl Marx himself would probably have been opposed to making such a choice, as his attitude towards dialectical method was far from being enthusiastic. Marx criticised dialecticians (even among socialists ${ }^{53}$ ) who were unable to see that their statements, no matter how ethically justified, cannot be scientifically proved. Nevertheless, disdaining dialectics as a social scientist, he recognised perfectly its political power to attract masses with a simple, coherent, future-oriented and never to be discredited as false, ${ }^{54}$ tool of forthcoming revolution. Lenin missed that Marxian scientific criticism of the dialectical method for two reasons. First, he was not interested in science as such, but in revolution. Second, as far as the truth and theory were concerned, he rather trusted Hegel, whose notion of science was dialectical, and so simpler to be learnt. ${ }^{55}$ And for Hegel dialectics was the only way to the truth.

There is one problem to be solved with dialectical truth, if it is to be used by a politician. Its universal character makes it impossible to be appointed directly to deal with particulars. To put it simply, dialectical truth does not reach individuality. The most particular level it is able to go down to, is the level of categories. In Marxism there are two such crucial categories grouping particulars (as 'particulars' means also particular citizens) worth being taken into account as far as political issues are concerned: proletariat and bourgeoisie. This way individuals are not individuals, but members of a particular group, in whom a dialectician recognises universals upon which he (or she) is obliged to act. We see a dog, but we should negate its individuality, not to respond to its particular behaviours (barking or waving the tail), but rather treat it according to our objective knowledge of canine nature, explains Lenin. ${ }^{56}$

There is nothing wrong with categories as such. There are politically useful, as it would be impossible to adjust every political action to every particular. Categories may vary in respect to their range and political purpose, and what is even more advantageous, criteria according to which they are constructed are demonstrable: workers are those hired by others, the poor are those whose income is lower than some established amount of money, citizens are those who possess citizenship, and so on. Nevertheless, categories constructed by unfettered dialecticians are much less stable, as their boundaries are softened thanks to the overlapping and basic categorization, being suggested by the truth itself. In regard to the truth, every particular can be viewed either as supporting, or denying it. And since denying the truth means being wrong, actions of those who question it (like Aristotle claiming Lenin's ideas to be a mere opinion) are hostile to the truth and logically deserve counter-measures. It would be unwise to let falsehood proliferate and impede political improvement. Such reasoning served Lenin well, though

53 Marx to Engels, 17 VIII 1870, www.marxists.org/archive/marx/works/download/Marx_Engels_Correspondence.pdf (access: 9.04.2018).

54 See: K. Marx, Capital Volume One: 1873 Afterword to the Second German Edition, www.marxists. org/archive/marx/works/1867-c1/p3.htm (access: 9.04.2018); K. Marx, F. Engels, Werke, Vol. XXII, Berlin (Ost) 1956, p. 217.

55 On complicated relations between Hegel, Marx and Lenin see: I. Barwicka-Tylek, Prawda i sens. Dialektyka - marksizm - komunizm, Kraków 2016.

56 V.I. Lenin, On the Question of Dialectics, www.marxists.org/archive/lenin/works/1914/cons-logic/ summary.htm (access: 9.04.2018). 
many of his collaborators could not understand its dialectical nuances. Using dialectics the leader of the Communist revolution could advise British Communists to collaborate with 'revisionist' enemies, as 'objectively' (not knowing what in fact they were doing) they worked for the sake of the Communist truth, so they had to be counted among temporary allies. In the same pamphlet Lenin ferociously criticised his colleagues for not being able to understand this simple dialectical reasoning and so being unable to serve the Communist truth. ${ }^{57}$

This reveals the next visible feature of politics based on unfettered dialectics: it can be implemented only with the help of a hierarchical organisation absolutely and at all costs loyal to its leader. Dialectical truth cannot be demonstrated, as it does not cease to be an opinion, against the zeal of its followers. If it could be used by individuals in their own process of deliberation antecedent to action (as phronesis assumes), practical inferences of such deliberations might differ, which is another bonus of opinion in the eyes of Aristotle, as then differences may be compared and assessed. Unlike opinion, truth excludes differences and makes only one process of deliberation valuable for action. The easiest way to achieve such a unity is to grant someone with the power to 'homologate' particular proposals. The leader becomes a kind of 'great interpreter', having the best recognition of the truth (sophia) and so entitled to give meaning to particulars to determine the actions required. This connection does not work in reverse (that is: observing a strong political leader only, we cannot be sure whether he has phronesis or not), but there are reasons to worry that exactly this model of politics, based on unfettered dialectics, is not rare in contemporary politics all around the world.

If the dialectical truth cannot reach particulars, neither can it reach authentic interpersonal relationships, and so it breaks the connection between politics and ethics that was so important to Aristotle. It is of course possible to claim that the truth would produce better, 'true' ethics, but for Aristotle ethics itself is born out of human nature, and not out of human knowledge, whether this knowledge is the truth or an opinion. Otherwise it would not have a universally regulative and normative character.

This is, in my opinion, a seminal error for an unfettered dialectician to make in his thinking. Practical wisdom must meet ethical requirements, as apart from being interestoriented it must take into account the universal goal, which would be the flourishing of humankind: not human flourishing on the ground of any theory, but the factual 'material' improvement of the quality of political relations within the community. That is why Aristotelian ethics assumes individual responsibility not in regard to knowledge (let it be the truth), but in regard to others (not necessarily having or sharing our knowledge). That is also why Aristotle claims that skilfulness in dialectical reasoning improves our interpersonal contacts and interactions. Realising and accepting only the opinionative status of dialectic opinions and actions, individuals must pay more attention to explaining themselves and to justifying their actions. Only then can they be understood by others as doing good. Of course, in areas in which the truth can be specified once and for all, it would be unethical to act against it, but the exact state of affairs is that political practice goes beyond the truth without violating it. Thales and 'the man from Sicily' both

57 V.I. Lenin, 'Left-Wing' Communism: An Infantile Disorder, www.marxists.org/archive/lenin/ works/1920/1wc/ (access: 9.04.2018). 
performed the same actions (effective and relying on science), and still the former could be rightly praised by his compatriots - as thanks to him they had a chance to learn that it is wrong to despise philosophy - while the latter could be banished on the basis of an opinion that imitating such actions would worsen the life of the community.

Aristotle would agree that there is no disagreement between scientific truth and ethics. But he would not agree with unfettered dialecticians, who would claim that it is possible to infer particular action directly from universal truth. Objective truth is necessary, so it excludes any choice. And it is the ethical quality of that choice what should be the basic concern for a phronimos. More than that: it demands rejecting any impulses external to the dialectical truth, even if they are spontaneously born in the acting person. As Lenin confessed to Maxim Gorki:

But often I can't listen to music. It acts on my nerves. It makes one want to say a lot of sweet nonsense and stroke the heads of people who live in a filthy hell-hole and yet can create such beauty. But you can't stroke anyone's head today - you'll get your hands cut off. The need is to beat them over the head, beat them mercilessly even though we, as an idea. Are against any coercion of people. Hm, hm... it's a hellishly difficult necessity. ${ }^{58}$

It is a mistake to question or to mock at this personally tragic dimension of dialectics for the unfettered dialectician himself. This individual tragedy significantly deepens dangers of political theories of that kind. Once they are put into action and take control over political reality, their impractical character is more and more 'productive' and more difficult to reverse. Not only external criticism, but also negative feelings of the dialectic politician strengthen his conviction that radical actions are necessary for the truth to prevail as soon as possible to ease all sufferings. Particulars are no longer to be taken at face value (the beauty of the music, the fact someone does create it, emotions being evoked), but they need to be reinterpreted first in the context of the assumed truth. This way they lack power to provide the politician with a feedback which could stimulate his reasoning and eventually lead to questioning his basic opinions. What can be changed are only actions or acting individuals, because they have to be related to the actual state of the world, in which the truth is yet to be established. Such flexibility of 'tactics', to use Lenin's favourite word, was caused by the particulars existing in the world in which the truth was yet to be established, and so it should not be perceived as a modification of the theory. As he never ceased explaining: "The Bolshevik slogans and ideas on the whole have been confirmed by history; but concretely things have worked out differently; they are more original, more peculiar, more variated than anyone could have expected." That is a very common way in which unfettered dialecticians justify introducing new proposals, even if they seem to be contradictory to the former ones. Variation of particulars, which for Aristotle was an argument to go beyond the truth and to look for a wisdom which would be able to save some consistency of our actions under conditions of uncertainty of the final outcome, is here used as an excuse for the lack of this consistency.

58 R. Service, Lenin: A Biography, London 2002, p. 276 in Polish translation (2003).

59 V.I. Lenin, Letters on Tactics, www.marxists.org/archive/lenin/works/1917/apr/x01.htm (access: 9.04.2018). 


\section{Conclusions}

European culture has always had faith in knowledge, assuming that the truth is an emancipating force, leading us towards a better - in an ethical sense - future. A careful reading of Aristotle, however, suggests that this propensity of ours should not be taken for granted without paying attention to the quality of thinking, to make sure that we use the label 'truth' adequately. Otherwise we risk producing 'truths' which cannot be demonstrated, and thus can be proved neither true, nor false. The problem is that such truths have equal, or perhaps even greater, political utility than the scientific truth. They are born out of dialectical reasoning, which has a great persuasive power and is by nature plausible in politics.

At the turn of the $21^{\text {st }}$ century it might look like our knowledge was scientific enough to structure a world order in which all societies would enjoy (or at least expect to enjoy) the benefits of democracy, and that this democracy, without dialectics, would offer more justice, and more stable economic development, all because it would be based on science. The spectacular fall of Communism in Central and Eastern Europe could be seen as a proof that dialectics is less practical than 'political science' for providing politicians and citizens with tools to carry on deliberation and action. There are, I believe, not many of those who still share such vision. The future foreseen at the end of the 80's by wise social scientists with numerous demonstrative facts to be presented as proofs, has not materialised, not because social scientists lie or are not wise enough, but because political practice cannot be determined in advance. And it cannot be determined as it includes reasoning, which is too creative to be pinned down by the truth itself.

The fact that we do not like dialectics does not make it vanish from politics. It only proves that we do not analyse our reasoning deeply enough, do not control it, and consequently cannot identify its misuses. Paradoxically, this is what makes dialectics more dangerous. Aristotle makes it clear that without dialectic faculties we would not be able to carry on practical political activity - which for him is the politics of successfully balancing particular self-interest against the common good. Those who are not able to understand the seminal difference between the truth and opinion, will never be able to use them correctly in deliberations which are concluded by their actions. And so, no matter how well they may prosper as politicians thanks to such actions, they do not deserve to be called phronimos. For Aristotle 'to practice' anything, it is not enough to claim that one rejects 'idealism', chooses 'pragmatism', or is a 'realist'. It is simply not enough to be able to influence the political reality and to force through one's decisions. It is not even enough to be successful at staying in power. Such facts do not tell the whole truth about politics. Practical wisdom requires conducting politics in some particular way, with respect to others and their opinions, which have exactly the same epistemological status, not on a declarative level, but... in practice. 'Ethical studies may fairly be called political', ${ }^{60}$ says Aristotle, as there is no political practice apart from ethical (simply accepting the mutual character of political relationships) behaviours. We need multivocal deliberative discourse in politics to bring about real differences in political life.

${ }^{60}$ Aristotle, Rhetoric, I.2. 
A healthy society must be, according to Aristotle, a diversified and dynamic system of cooperation, not a close-knit family. ${ }^{61}$

Of course this view of politics can be questioned. After all it is only an opinion. Nevertheless, it is an opinion worth being reminded of, and, even more, of being practiced, unless we really deny any important political difference in living either under the conditions of Athenian democracy (with all of its flaws) dominated by Pericles, or Russian Communism dominated by Lenin (with all of its achievements like industrialisation or electrification). Of course from today's perspective the difference is clearly visible, but such a historical conclusion has only limited political significance. It proves perhaps the bankruptcy of Communism, but does not allow for the identification of other concepts and ideas which - due to their construction, not their merit - capture minds in exactly the same way. In my opinion studying the history of political thought which would include the history of political thinking, could be a link necessary for binding historical and political research together, and thus could have very practical value.

We live in a world in which, against all predictions, sources of uncertainty multiply, which makes it relatively easy for politicians to construct new cognitive shelters for their societies, using the language which for now still binds us all: the language of democracy. Aristotle provides us with quite useful methodological tools to examine the practicality of particular political proposals, which means also assessing their possible contribution for evoking actions oriented towards the common good, and so deserving to be called not only efficient, but first of all, good actions. Using these tools requires admitting that political activity is closer to ethics than to science, and cutting that bond is risky. To make this bond really work, however, it is important to introduce a rigid order into any political thinking. The order in which the difference between scientific reasoning, leading to the truth, and dialectical reasoning, leading to justified opinion, is respected. And here philosophers as well as citizens are equally prone to make wrong judgements, especially if they are not sufficiently educated in the requirements of practical wisdom. We are free to buy a house only because we like the wallpaper on the bathroom walls, and it is not necessarily a wrong decision. On the other hand, the choice we make observing that the condition of the wallpaper is getting worse when the bathroom is used, can be judged either as a good, or as a bad action. From our individual perspective it may look like a smart idea to invent creative means to protect the wallpaper we like so much, even if that means cutting off the water. This decision may be in fact profitable, as our bills would fall, but still such actions may be classified as 'impractical' in the Aristotelian sense. As long as there are needs shared by us all - in spite of the fact that we may only conjecture what they are, without being able to grasp the truth of human nature - it is better to get rid of the wallpaper, just as it is better to revise a political opinion, before it starts to work against us.

${ }^{61}$ Aristotle, Politics, 1261a. 


\section{Bibliography}

Aristotle in twenty-three volumes, transl. P.H. Wicksteed et al., London 2005.

Barwicka-Tylek I., Prawda i sens. Dialektyka - marksizm - komunizm, Kraków 2016.

Berlin I., Karl Marx. His Life and Environment, Oxford 1996.

Gouldner A.V., The Two Marxism, New York 1980.

Heidegger M., Hegel und die Griechen, Lecture in Heidelberg, 26.07.1958; English translation online: Hegel and the Greeks, www.morec.com/hegelgre.htm (access: 3.04.2018).

Labarrière J.-L., Phronesis [in:] Dictionary of Untranslatables: A Philosophical Lexicon, E. Apter, J. Lezra, M. Wood (eds.), Princeton-Oxford 2014, pp. 777-783.

Lenin V.I., 'Left-Wing' Communism: An Infantile Disorder, www.marxists.org/archive/lenin/ works/1920/lwc/ (access: 9.04.2018).

Lenin V.I., Letters on Tactics, www.marxists.org/archive/lenin/works/1917/apr/x01.htm (access: 9.04.2018).

Lenin V.I., On the Question of Dialectics, www.marxists.org/archive/lenin/works/1914/cons-logic/summary.htm (access: 9.04.2018).

Lukács G., Geschichte und Klassenbewusstsein. Studien über marxistische Dialektik, Berlin 1923.

Lyotard J.-F., The Postmodern Condition: A Report on Knowledge, transl. G. Bennington, B. Massumi, Minneapolis 1993, www.faculty.georgetown.edu/irvinem/theory/Lyotard-PostModernCondition1-5.html (access: 3.04.2018).

Marks J., Fried snowballs, London 1990.

Marx K., Capital Volume One: 1873 Afterword to the Second German Edition, www.marxists.org/ archive/marx/works/1867-c1/p3.htm (access: 9.04.2018).

Marx K., Engels F., Werke, Vol. XXII, Berlin (Ost) 1956.

McKeon R., Dialectic and Political Thought and Action, "Ethics. An International Journal of Social, Political, and Legal Philosophy" 1954, Vol. LXV (1), pp. 1-33.

Ollman B., Dance of Dialectic: Steps in Marx's Method, Urbana-Chicago 2003.

Pericles' Funeral Oration [in:] Thucydides, Peloponnesian War, Book 2.34-46, www.sourcebooks.fordham.edu/ancient/pericles-funeralspeech.asp (access: 03.04.2018).

Selected Dialogues of Plato, transl. B. Jowett, New York 2001.

Service R., Lenin: A Biography, London 2002.

Skinner Q., Meaning and Understanding in the History of Ideas, "History and Theory" 1969, Vol. 8 (1), pp. 3-53.

Stróżewski W., Istnienie i sens, Kraków 1984.

Szacki J., Dylematy historiografii idei [in:] idem, Dylematy historiografii idei oraz inne szkice i studia, Warszawa 1991.

Ulam A., The Bolsheviks, Cambridge 1998.

\section{Niuanse mądrości praktycznej. Dlaczego Arystoteles gtosowatby raczej na Peryklesa niż na Lenina?}

\section{Streszczenie}

Artykuł przybliża pojęcie mądrości praktycznej (fronesis), która dla Arystotelesa odgrywa kluczową rolę w działalności politycznej. W przeciwieństwie do mądrości filozoficznej (sofia), fronesis wymaga wiedzy dotyczącej konkretów, czyli rzeczy, które „mogą być inaczej”. Taka wiedza nie jest dana raz na zawsze jako uniwersalna prawda, ale musi być nieustannie uaktualniana i rewidowana, by sprostać 
oczekiwaniom zorientowanych na przyszłość działań politycznych. Dlatego, jak się wydaje, odpowiada ona Arystotelesowskiemu rozumieniu opinii będącej wynikiem myślenia dialektycznego, odróżnianego od myślenia naukowego, polegającego na demonstracji. Dialektyka może być postrzegana jako klucz do polityki i nie powinna przesłaniać tego faktu uzasadniona krytyka tych teoretyków i polityków, którzy, jak Lenin, używali jej, nie respektując różnicy między prawdą a opinią. Porównanie Lenina z Peryklesem, który występuje w Etyce nikomachejskiej jako polityk obdarzony fronesis, pozwala wysnuć wniosek, że krytyczne badanie poszczególnych stanowisk politycznych nie powinno ograniczać się do ich merytorycznej treści, idei, pojęć czy wysuwanych propozycji zmian, ale musi brać również pod uwagę głębszy poziom myślenia politycznego, którego są wynikiem. Konkludując, niewłaściwe użycie dialektyki wyrządza szkody zarówno teorii, jak i praktyce politycznej. 